\title{
PENGARUH PENDEKATAN PEMBELAJARAN KOOPERATIF TWO-STAY TWO-STRAY TERHADAP HASIL BELAJAR IPA MATERI SUMBER DAYA ALAM
}

\author{
Warsi Suprihyatin \\ SD Negeri Karangdadap, Banyumas, Indonesia \\ Email: warsisuprihyatin23@gmail.com
}

\begin{abstract}
This research was aimed to figure out the effect of Two-Stay Two-Stray cooperative learning approach to natural science subject learning achievement on the material of natural resource on the fourth graders of $S D$ egeri Karangdadap. Learning achievement studied consisted 3 aspects; cognitive, affective, and psychomotoricaspect. The subject of the research was the the fourth graders of SD negeri Karangdadap covered 2 classes, class IVA totalled 23 studens and IV B totalled 26 studens. This research was conducted by using experimental method, class IV A as an experimental class and class IV B as controlled class. This research was started by pre-tes, treatment, and pos-test, data collecting technique employed was test and no-test. Non-test technique was used to collect affective aspect data by quesionnarie and psychomotoric aspect by rating scale by using indicator of responsibility attitude. The obtained data were analyzed by Man Whitney test based on the calculation result, obtained cognitive aspect $Z<-Z \alpha / 2$ atau $-2,213<-0,01$; affective aspect $Z<-Z \alpha / 2$ or $2,282<-0,01$; psychomotoric aspect $Z<-Z \alpha / 2$ atau $-2,395<-0,01$. Based on the above result, it could be concluded that there was effect on the application of Two-Stay Two-Stray cooperative lesrning approach to natural science subject learning achievement on the material of natural resource on the fourth graders of SD negeri Karangdadap on cognitive, affective, and psychomotoric aspects.
\end{abstract}

Keywords: Learning Achievement, Two-Stay Two-Stray Cooperative Learning Approach, Natural Resource.

Abstrak.Penelitian ini bertujuan untuk mengetahui pengaruh pendekatan pembelajaran kooperatif Two-Stay Two-Stray terhadap prestasi belajar mata pelajaran IPA pada materi sumber daya alam pada siswa kelas empat SD egeri Karangdadap. Prestasi belajar yang dipelajari terdiri dari 3 aspek; aspek kognitif, afektif, dan psikomotorik. Subjek penelitian adalah siswa kelas IV SD Negeri Karangdadap yang meliputi 2 kelas, kelas IVA berjumlah 23 siswa dan IV B berjumlah 26 siswa. Penelitian ini dilakukan dengan menggunakan metode eksperimen, kelas IV A sebagai kelas eksperimen dan kelas IV B sebagai kelas kontrol. Penelitian ini dimulai dengan pre-tes, perawatan, dan post-test, teknik pengumpulan data yang digunakan adalah tes dan no-tes. Teknik non-tes digunakan untuk mengumpulkan data aspek afektif oleh kuesioner dan aspek psikomotorik dengan skala penilaian dengan menggunakan indikator sikap tanggung jawab. Data yang diperoleh dianalisis dengan uji Man Whitney berdasarkan hasil perhitungan, diperoleh aspek kognitif $Z<-Z \alpha / 2$ atau $-2,213<-0,01$; aspek afektif $Z$ $<-Z \alpha / 2$ atau $-2.282<-0,01$; aspek psikomotorik $Z<-Z \alpha / 2$ atau $-2,395<-0,01$. Berdasarkan hasil di atas, dapat disimpulkan bahwa ada pengaruh penerapan pendekatan pembelajaran kooperatif tipe Two-Stay Two-Stray terhadap prestasi belajar mata pelajaran IPA pada materi sumber daya alam pada siswa kelas IV SD Negeri Karangdadap pada kognitif, aspek afektif, dan psikomotorik.

Kata kunci: Prestasi Belajar, Kooperatif Two-Stay Two-Stray, Sumber Daya Alam.

\section{PENDAHULUAN}

Mata pelajaran IPA yang diajarkan di Sekolah Dasar merupakan salah satu mata pelajaran wajib yang harus dipelajari oleh peserta didik, oleh sebab itu dibutuhkan kemampuan dan keterampilan guru untuk menyampaikan materi secara efektif sehingga peserta didik mudah menerima dan memahami penjelasan yang disampaikan oleh guru. Penyampaian materi secara efektif dapat dilakukan dengan cara memilih metode dan model pembelajaran yang sesuai dengan materi.

Perkembangan teori pembelajaran saat ini banyak menghasilkan modifikasi model-model pembelajaran yang didalamnya terdapat pendekatanpendekatan yang bervariasi yang bertujuan 
untuk menciptakan pembelajaran yang menyenangkan dan meningkatkan hasil belajar peserta didik. Penggunaan pendekatan pembelajaran yang menarik dan menyenangkan dapat membuat peserta didik tertarik untuk mengikuti pembelajaran di kelas. Namun tidak mudah bagi guru untuk menentukan pendekatan pembelajaran yang sesuai untuk mata pelajaran yang akan diajarkan karena setiap pendekatan pembelajaran memiliki karakteristik pembelajaran yang berbeda. Pendekatan pembelajaran yang berkembang saat ini juga belum tentu dikuasai oleh guru dan dapat diaplikasikan pada saat mengajar, karena guru cenderung masih menggunakan ceramah atau pembelajaran berfokus pada guru yang menyebabkan peserta didik bosan dan kurang tertarik dengan pembelajaran yang disampaikan guru.

Kondisi di lapangan masih menunjukan bahwa pembelajaran yang dilakukan oleh guru masih berpusat pada guru, guru masih menggunakan ceramah saat pembelajaran. Peserta didik kurang aktif dalam pembelajaran, dan masih malumalu untuk mengungkapkan sebuah pendapat atau menyampaikan jawaban. Dari permasalahan tersebut peneliti mencoba untuk melakukan sebuah penelitian dengan menerapkan salah satu pendekatan pembelajaran yang dapat mengoptimalkan aktivitas belajar peserta didik di kelas adalah pendekatan pembelajaran kooperatif Two-Stay TwoStray. Pendekatan pembelajaran kooperatif Two-Stay Two-Stray memiliki beberapa kelebihan diantaranya adalah pembelajaran akan lebih bermakna, peserta didik akan lebih aktif, pembelajaran berpusat pada Peserta didik, Peserta didik akan lebih berani mengungkapkan pendapatnya, meningkatkan kemampuan berbicara Peserta didik, dan dapat meningkatkan minat peserta didik. Namun pendekatan pembelajaran kooperatif Two-Stay TwoStray juga memiliki kekurangan diantaranya yaitu memerlukan waktu yang lama, peserta didik yang kurang cenderung akan bergantung pada peserta didik yang pintar, membutuhkan banyak persiapan. Meskipun memiliki kekurangan tetapi pendekatan pembelajaran ini mampu membantu peserta didik yang kurang aktif atau pendiam agar dapat bersosialisasi dengan baik dan dapat menyampaikan gagasan dalam kelompoknya terhadap kelompok belajar yang lain.

Masalah yang dirumuskan berdasarkan latar belakang yang ada adalah: (1) Bagaimana pengaruh pendekatan pembelajaran Two-Stay Two-Stray terhadap hasil belajar IPA aspek kognitif peserta didik kelas IV SD Negeri Karangdadap, (2) Bagaimana pengaruh pendekatan pembelajaran Two-Stay Two-Stray terhadap hasil belajar IPA aspek afektif peserta didik kelas IV SD Negeri Karangdadap, (3) Bagaimana pengaruh pendekatan pembelajaran Two-Stay Two-Stray terhadap hasil belajar IPA aspek psikomotor peserta didik kelas IV SD Negeri Karangdadap.

Penelitian ini bertujuan untuk: (1) Mengetahui pengaruh pendekatan pembelajaran Two-Stay Two-Stray terhadap hasil belajar IPA aspek kognitif peserta didik kelas IV SD Negeri Karangdadap, (2) Mengetahui pengaruh pendekatan pembelajaran Two-Stay Two-Stray terhadap hasil belajar IPA aspek afektif peserta didik kelas IV SD Negeri Karangdadap, (3) Mengetahui pengaruh pendekatan pembelajaran Two-Stay Two-Stray terhadap hasil belajar IPA aspek psikomotor peserta didik kelas IV SD Negeri Karangdadap. Menurut Johnson \& Johnson, 1993 (Warsono, 2012: 161) mendefisinikan pembelajaran kooperatif adalah penerapan 
pembelajaran terhadap kelompok kecil sehingga para peserta didik dapat bekerja sama untuk memaksimalkan pembelajaran anggota kelompok yang lain. Menurut Huda (2003: 207) Model Two stay two stray merupakan sistem pembelajaran kelompok dengan tujuan agar peserta didik dapat saling bekerjasama, bertanggungjawab, saling membantu memecahkan masalah dan saling mendorong satu sama lain untuk saling berprestasi dan melatih peserta didik untuk bersosialisasi dengan baik. Menurut Sudjana (2010: 25) mengemukakan bahwa hasil belajar adalah kemampuankemampuan yang dimiliki peserta didik setelah ia menerima pengalaman belajarnya. Menurut H.W Fowler, 1986 (Trianto, 2010: 136) IPA adalah pengetahuan yang sistematis dan dirumuskan, yang berhubungan dengan gejala-gejala kebendaan dan didasarkan terutama atas pengamatan dan deduksi.

\section{METODE PENELITIAN}

Metode yang dilakukan dalam penelitian ini adalah metode penelitian eksperimen. Penelitian ini dilakukan di SD negeri Karangdadap, kecamatan Kalibagor, kabupaten Banyumas. Waktu penelitian yaitu pada bulan Mei 2014. Populasi dalam penelitian ini adalah seluruh siswa kelas IV SD N Karangdadap Kabupaten Banyumas Tahun Pelajaran 2013/ 2014 yang berjumlah 45 siswa. Pengambilan sampel pada penelitian ini yaitu dengan cara pengundian atau lotre, kelas IV A sebagai kelas eksperimen dan kelas IV B sebagai kelas kontrol. Penelitian terdapat dua variabel yaitu pendekatan pembelajaran Two Stay Two Stray (X) dan hasil belajar siswa yang mencakup aspek kognitif, aspek afektif, dan aspek psikomotor (Y). teknik pengumpulan data menggunakan tes tertulis untuk aspek kognitif, angket untuk aspek afektif, dan skala sikap untuk aspek psikomotor. Uji analis data yang dilakukan adalah uji homogenitas dan uji hipotesis.

\section{HASIL DAN PEMBAHASAN Hasil belajar IPA aspek kognitif}

Berdasarkan hasil perhitungan maka dapat diketahui bahwa $Z=-2,213$. Kriteria pengambilan keputusannya adalah $\mathrm{H}_{0}$ diterima apabila $-\mathrm{Z}_{\alpha / 2} \leq \mathrm{Z} \leq \mathrm{Z} \alpha / 2 \quad \mathrm{H}_{0}$ ditolak apabila $\mathrm{Z}>\mathrm{Z} \alpha / 2$ atau $\mathrm{Z}<-\mathrm{Z}_{\alpha / 2}$. Dari perhitungan yang telah dilaksanakan diperoleh bahwa $\mathrm{Z}<-\mathrm{Z}_{\alpha / 2}$ atau $-2,213<$

0,01. Berdasarkan hasil dari uji hipotesis pertama menyatakan bahwa $\mathrm{H}_{0}$ ditolak dan $\mathrm{H}_{\mathrm{a}}$ diterima. Sehingga terdapat pengaruh pendekatan pembelajaran kooperatif Two Stay Two Stray terhadap hasil belajar siswa aspek kognitif pada mata pelajaran IPA materi Sumber daya alam di kelas IV SD Negeri Karangdadap. Hasil dari uji hipotesis ini membuktikan bahwa pendekatan pembelajaran kooperatif Two Stay Two Stray mampu meningkatkan hasil belajar aspek kognitif oleh sebab itu pendekatan pembelajaran kooperatif $T w o$ Stay Two Stray ini efektif untuk pembelajaran IPA di kelas IV.

\section{Hasil belajar IPA aspek afektif}

Berdasarkan hasil perhitungan maka dapat diketahui bahwa $Z=-2,282$. Kriteria pengambilan keputusannya adalah $\mathrm{H}_{0}$ diterima apabila $-\mathrm{Z} a / 2 \leq \mathrm{Z} \leq \mathrm{Z} a / 2 \quad \mathrm{H}_{0}$ ditolak apabila $\mathrm{Z}>\mathrm{Z}_{\alpha / 2}$ atau $\mathrm{Z}<-\mathrm{Z}_{\alpha / 2}$. Dari perhitungan yang telah dilaksanakan 
diperoleh bahwa $\mathrm{Z}<-\mathrm{Z}_{\alpha / 2}$ atau $-2,282<-$

0,01. Berdasarkan hasil dari uji hipotesis kedua menyatakan bahwa $\mathrm{H}_{0}$ ditolak dan $\mathrm{H}_{\mathrm{a}}$ diterima. Sehingga terdapat pengaruh pendekatan pembelajaran kooperatif Two Stay Two Stray terhadap hasil belajar siswa aspek afektif pada mata pelajaran IPA materi Sumber daya alam di kelas IV SD Negeri Karangdadap.

\section{Hasil belajar IPA aspek psikomotor}

Berdasarkan hasil perhitungan maka dapat diketahui bahwa $Z=-2,395$. Kriteria pengambilan keputusannya adalah $\mathrm{H}_{0}$ diterima apabila $-\mathrm{Z} a / 2 \leq \mathrm{Z} \leq \mathrm{Z} a / 2 \quad \mathrm{H}_{0}$ ditolak apabila $\mathrm{Z}>\mathrm{Z}_{\alpha / 2}$ atau $\mathrm{Z}<-\mathrm{Z}_{\alpha / 2}$.

Dari perhitungan yang telah dilaksanakan diperoleh bahwa $\mathrm{Z}<-\mathrm{Z}_{a / 2}$ atau $-2,395<-$

0,01. Berdasarkan hasil dari uji hipotesis ketiga menyatakan bahwa $\mathrm{H}_{0}$ ditolak dan $\mathrm{H}_{\mathrm{a}}$ diterima. Sehingga terdapat pengaruh pendekatan pembelajaran kooperatif Two Stay Two Stray terhadap hasil belajar siswa aspek psikomotor pada mata pelajaran IPA materi Sumber daya alam di kelas IV SD Negeri Karangdadap.

\section{SIMPULAN DAN SARAN}

Berdasarkan hasil penelitian dan analisis data maka dapat diperoleh kesimpulan sebagai berikut: (1) Adanya pengaruh pendekatan pembelajaran kooperatif Two Stay Two Stray terhadap hasil belajar IPA materi sumber daya alam aspek kognitif peserta didik kelas IV SD Negeri Karangdadap. Hal tersebut terbukti dari hasil uji hipotesis yaitu $\mathrm{Z}<-\mathrm{Z}_{\alpha / 2}$ atau

$-2,213<-0,01$ maka $\mathrm{H}_{0}$ ditolak dan $\mathrm{H}_{\mathrm{a}}$ diterima. Sehingga dapat dinyatakan bahwa pendekatan pembelajaran kooperatif $T w o$
Stay Two Stray efektif digunakan dalam pembelajaran IPA kelas IV, (2) Adanya pengaruh pendekatan pembelajaran kooperatif Two Stay Two Stray terhadap hasil belajar IPA materi sumber daya alam aspek afektif peserta didik kelas IV SD Negeri Karangdadap. Hal tersebut terbukti dari hasil uji hipotesis yaitu $\mathrm{Z}<-\mathrm{Z} a / 2$ atau

$-2,282<-0,01$ maka $\mathrm{H}_{0}$ ditolak dan $\mathrm{H}_{\mathrm{a}}$ diterima. Sehingga dapat dinyatakan bahwa pendekatan pembelajaran kooperatif Two Stay Two Stray efektif digunakan dalam pembelajaran IPA kelas IV, (3) Adanya pengaruh pendekatan pembelajaran kooperatif Two Stay Two Stray terhadap hasil belajar IPA materi sumber daya alam aspek psikomotor peserta didik kelas IV SD Negeri Karangdadap. Hal tersebut terbukti dari hasil uji hipotesis yaitu $\mathrm{Z}<-\mathrm{Z}_{\alpha / 2}$ atau

$-2,395<-0,01$ maka $\mathrm{H}_{0}$ ditolak dan $\mathrm{Ha}$ diterima. Sehingga dapat dinyatakan bahwa pendekatan pembelajaran kooperatif Two Stay Two Stray efektif digunakan dalam pembelajaran IPA kelas IV.

Saran dalam penelitian ini adalah sebagai berikut: (1) Guru harus benar-benar memperhatikan waktu yang digunakan dalam pembelajaran karena proses pembelajaran yang dikakukan membutuhkan waktu yang lama sehingga pembelajaran dapat dilaksanakan dengan baik dan tidak kekurangan jam pelajaran atau melebihi jam pelajaran yang telah ditentukan, (2) Guru harus lebih aktif memonitor setiap kelompok agar diskusi mereka dapat berjalan dengan baik dan siswa mau belajar dalam kelompoknya, (3) Guru harus dapat menjadi moderator jika terdapat perselisihan pendapat sehingga perselisihan tersebut dapat diselesaikan dengan cara diskusi. 


\section{DAFTAR PUSTAKA}

Huda, M. (2013). Model-Model Pengajaran Dan Pembelajaran. Yogyakarta : Pustaka Belajar.

Warsono dan Hariyanto. (2012). Pembelajaran Aktif Teori dan
Sudjana. (2010). Penilaian Hasil Proses Belajar Mengajar. Bandung : PT Remaja Rosda karya.

Trianto. ( 2010). Model Pembelajaran Terpadu. Jakarta : PT Bumi Aksara. Assesmen. Bandung: Remaja Rosdakarya 